\title{
Quality Enhancement of Falcataria-Wood through Impregnation $^{1}$
}

\author{
Ihak SUMARDI ${ }^{2, \dagger} \cdot$ Atmawi DARWIS ${ }^{2} \cdot$ Sahriyanti $\mathrm{SAAD}^{3} \cdot$ \\ Muhammad Navis ROFII ${ }^{4}$
}

\begin{abstract}
The purpose of this research is to determine the efficiency of impregnation usingphenol formaldehyde resin to enhance Falcataria wood's stability and better mechanical properties. Impregnation process was carried out after moisture content stabilized at $12 \%$ on samples with a dimension of $20 \mathrm{~mm} \times 20 \mathrm{~mm} \times 300 \mathrm{~mm}$ at various concentrations and pressure time. Dimensional stability was evaluated by thickness swelling (TS) and anti-swelling efficiency (ASE) and the young's modulus was conducted according to BS 573. The mechanical properties and dimensional stability of impregnated wood were evaluated. Dimensional stability and mechanical properties of Falcataria wood were successfully increased after impregnation. PF impregnation can improve the mechanical properties and the density from $0.26 \mathrm{~g} / \mathrm{cm}^{3}$ to $0.30 \mathrm{~g} / \mathrm{cm}^{3}$ even with only $10 \%$ of weight percent grain. Dimensional stability increases with increasing resin concentration and time pressure. The highest increase in mechanical properties was found at a higher concentration of PF. The penetration of PF into the wood's cell darkens the color of impregnated wood.
\end{abstract}

Keywords: phenol formaldehyde, pressure time, concentration phenol formaldehyde, weight percent grain, anti-swelling efficiency

\section{INTRODUCTION}

Wood is a renewable natural resource, abundantly available and serves various functions for human life, e.g., paper making, construction materials, particle boards, energy resources, and as raw material for various industrial needs. In general, there are two characteristics of wood, namely high-density and low-density wood.The low-density wood lacks strength and has low dimensional stability, thus limited in use. Most low-density wood is being used for fuel purposes; however, this type of wood can be used for other purposes (e.g., furniture, home construction, and office equipment) after the wood quality enhancement process such as the thermal compression (Lee and Lee, 2018), heat treatments (Priadi et al., 2019), Heat treatment and hygroscopic performance (Chang et al., 2019) and the polymer impregnation (Oh and Park, 2015).

The impregnation process can improve the wood

\footnotetext{
${ }^{1}$ Date Received February 5, 2020, Date Accepted August 31, 2020

${ }^{2}$ School of Life Sciences and Technology, Institut Teknologi Bandung, Jalan Ganesha 10 Bandung 40132, Indonesia

${ }^{3}$ Faculty of Forestry, Hasanudin University, Jalan Perintis Kemerdekaan Makassar 9024, 5 Indonesia

${ }^{4}$ Faculty of Forestry, Universitas Gadjah Mada, Jalan Agro 1, Bulaksumur, Yogyakarta 55281, Indonesia

$\dagger$ Corresponding author: Ihak SUMARDI (e-mail: ihak@sith.itb.ac.id, ORCID: 0000-0002-6617-6186)
} 
mechanical properties by compacting the wood density to a higher level without damaging the cellular structures (Kamke, 2006), increasing resistance to termite attack (Arsyad et al., 2019). This process resulted in a better physical and mechanical wood properties compared with the immersion process (Hadi et al., 2019). Thus, the application of newly developed impregnation technology can expand the use of low-density wood for structural applications that were previously limited. A recent study reportedthat low weight phenol formaldehyde (PF) resins can be used to improve wood properties through impregnation (Izreen et al., 2011; Furuno et al., 2004; Shams et al., 2004; Hartono et al., 2016). PF resins can penetrate and swell the wood's cell walls and increase the wood's dimensional stability (Franke et al., 2017; Shams and Yano, 2004; Gabrielli and Kamke, 2010; Farmers, 1967), form the rigid cross-tissues in the drying process (Stamm, 1959), and reduce hygroscopicity (Hill, 2006). The impregnation and compregnation processes are the most commercially successful methods to increase the wood's dimensional stability that resulted in up to 75 and $95 \%$ anti-swelling efficiency (ASE) at 35 and $30 \%$ weight gain (WPG) (Stamm, 1959).

PF penetration into the cell wall is a parameter of the impregnation effectiveness level. Furuno et al. (2004) reported that the wood cell walls can be well penetrated with low PF molecular weight (MN) with an average of 290-480. Meanwhile, a higher PF (i.e., $820 \mathrm{MN}$ ) is difficult to penetrate the wood cell walls, thus did not significantly affect the wood's dimensional stability. A low molecular PF impregnation has a plasticizing effect on the wood's cell walls (Shams and Yano, 2004). Therefore, the wood cell walls were not damaged when pressure applied during the PF impregnation process and subsequently cure $\mathrm{PF}$ in the wood cell walls (Furuno et al., 2004).

The PF impregnation process into the wood cell walls is one of the most effective ways to increase wood density which improves its physical and mechanical properties. For that reason, this study aimed to improve the physical and mechanical properties of a low-density falcataria woodto increase its utilization as one of the materials originated from renewable natural resources.

\section{MATERIALS and METHODS}

\subsection{Materials}

Falcataria (Paraserianthes falcataria(L) Nelson) wood was provided from the local source. Each wood specimens used for the physical and mechanical properties testing have the measurement of $20 \mathrm{~mm} \times 20$ $\mathrm{mm} \times 300 \mathrm{~mm}$ and were free of defects referred to the British Standard for Testing Small Wood Specimens, BS-373: 1957. All samples were conditioned at $25^{\circ} \mathrm{C}$ and $65 \% \mathrm{RH}$ up to constant weight before the impregnation process. The moisture content of the Falcataria samples was $12 \%$ with wood density ranging from 0.23 to $0.30 \mathrm{~g} / \mathrm{cm}^{3}$. The phenol formaldehyde (PF) resin used has a solid content of $42.05 \%$ and an average molecular weight of 780 and was supplied by PT. Palmolive Indonesia (Table 1).

Table 1. Characteristic of phenol formaldehyde resin

\begin{tabular}{ll}
\hline Resin Properties & Value \\
\hline \hline Viscosity @ $25^{\circ} \mathrm{C}$ (poise) & 2.27 \\
Specific Gravity @ $25^{\circ} \mathrm{C} / 4^{\circ} \mathrm{C}$ & 1.200 \\
Gelation Time $135^{\circ} \mathrm{C}(\mathrm{min}$.) & $12{ }^{\prime} 50^{\prime}$ \\
Resin Content @ $135^{\circ} \mathrm{C}(\%)$ & 42.05 \\
Molecular Weight $(\mathrm{Mn})$ & 780 \\
$\mathrm{pH}\left(\right.$ meter $\left./ 25^{\circ} \mathrm{C}\right)$ & 12.45 \\
\hline
\end{tabular}

\subsection{Impregnation process}

The impregnation process was carried out at room temperature and after the sample's moisture content was stabilized at approximately $12 \%$. Samples were 
placed in an impregnation chamber and vacuum-pressured at $50 \mathrm{~cm} \mathrm{Hg}$ for 5 minutes. A load is placed on top of the test sample to prevent the sample from floating during the impregnation process. Then, phenol formaldehyde resin was inserted through available channels in the chamber until the test sample sank. The chamber was closed again and vacuum-pressed to $10 \mathrm{~kg} / \mathrm{cm}^{2}$ with different timings accordingly. The samples were then removed from the chamber and the excess PF was removed from the sample surface.

Next, specimens were wrapped with aluminum foils and cured at $90^{\circ} \mathrm{C}$ for $24 \mathrm{~h}$ and conditioned at $25^{\circ} \mathrm{C}$ and $65 \% \mathrm{RH}$ for 1 month until the moisture content stabilized. In every stage of the process, the specimens' weight was measured to determine the polymer loading. The different treatment used were: a) concentration PF of $15 \%$ with various pressure time: 0,15 , 30, 45, 60, 90 and 120 minutes; b) pressure time 45 minutes with various concentration PF: $0,5,10,15,20$ and $25 \%$.

The weight percent grain (WPG) after impregnation process was calculated as shown in the Equation 1.

$$
W P G=\frac{W_{1}-W_{0}}{W_{0}} \times 100 \%
$$

$$
\begin{aligned}
& W P G=\text { weight percent grain }(\mathrm{gr}) \\
& W_{0}=\text { weight before impregnation }(\mathrm{gr}) \\
& W_{1}=\text { weight after impregnation }(\mathrm{gr})
\end{aligned}
$$

\subsection{Specimen testing and evaluation}

Beforetesting, the samples were conditioned in a room at a relative humidity of $65 \%$ and a temperature of $25^{\circ} \mathrm{C}$. Dimensional stability was evaluated by thickness swelling (TS) and anti-swelling efficiency (ASE) by measuring the mass and volume changes before and after swelling. Each specimen was weighed and measured in thickness, width, and length to determine their volume. Ten samples with a dimension of $20 \mathrm{~mm}$ $\times 20 \mathrm{~mm} \times 20 \mathrm{~mm}$ were soaked in immersion water for 24 hours to represent the swelling conditions. Samples' weight and volume were then measured again. Thickness swelling (TS) was calculated using an average thickness measurementand represents the amount of swelling in wet conditions at $12 \%$ moisture content (Eq. 2). ASE was calculated using the formula described in Eq. 3.

$$
T S=\frac{V_{1}-V_{0}}{V_{0}} \times 100
$$

where TS is volumetric swelling coefficient, $V_{1}$ is volume after water test, and $V_{0}$ is $12 \% \mathrm{MC}$ volume after impregnation process.

$$
A S E=\frac{S_{1}-S_{0}}{S_{0}} \times 100
$$

where ASE is anti-swelling efficiency, $S_{1}$ is volumetric swelling impregnated-wood specimen, and $S_{0}$ is volumetric swelling coefficient of control specimen.

Modulus of elasticity (MOE) and modulus of rupture (MOR) were evaluated before and after the impregnation process using the bending strength tests following the British standard 373. The three-point bend test was carried out using a universal testing machine (UTM) by placing the load on the sample until the sample breaks. The loading speed was $10 \mathrm{~mm} / \mathrm{mi}$ nute and supporting spans was $280 \mathrm{~mm}$ test sample. There were five replication samples in this test which were determined under an air-dried condition.

To identify the PF impregnation into the cell wall, random specimens were selected from each treatment and inspected visually by macro photographs (50× magnification) and observed by SEM analysis on the transverse surface.

\subsection{Data analysis}

The data gathered was analyzed using one-way analysis of variance (ANOVA) followed by Duncan's multiple range test to analyze differences between 
levels. All statistical tests were carried out using SAS (SAS Institute Inc, 2004) at a 95\% confidence level.

\section{RESULTS and DISCUSSION}

\subsection{Physical properties}

In general, the density increased alongwith increasing concentration $\mathrm{PF}$ and pressure time as shown in Table 2. Air-dry density values of the specimens ranged between $0.26-0.30 \mathrm{~g} / \mathrm{cm}^{3}$ (Table 2). The density of impregnated wood was higher compared to control specimens. The impregnated wood with pressure time of 120 minutes had a WPG increase up to $7.12 \%$. The $25 \%$ PF concentration also increased the WPG up to $10.53 \%$. The combination of PF concentration of higher PF concentration and longer pressure time could increase the density of impregnated wood compared to control specimens. The increase of impregnated-wood density was probably related to the permeability properties of wood. The vacuum process during impregnation resulted in a higher wood porosity, thus it was easier for PF to penetrate the cell wall (Fig. 1).

The stained wood cell walls (Fig. 1 T30-T120) in- dicate the presence of PF. The color difference made it easy to identify the PF penetration in the cell walls. The density of the impregnated wood increased, even with the use of high molecule PF. This result is contrary to a study of Furuno et al. (2004) where a high molecule PF cannot penetrate the cell wall.

Fig. 2 provides a qualitative SEM analysis of $15 \%$ $\mathrm{PF}$ at different pressure times. As shown in the figure, PF with high molecule weight could penetrate to Falcataria wood cell walls. The dark color was related to PF penetration into the lumen cell (Fig. 1). Several studies showed that high molecular weight PF resins can increase the dimensional stability of solid wood and composite wood, although the increase in stability was lower when using low molecular weight $\mathrm{PF}$ (Grinins et al., 2019; Biziks et al., 2019; Franke et al., 2018; Stamm and Baechler, 1960). Furthermore, Rowell (1999) suggested that low molecular weight resins are easier to penetrate the wood's cell walls compared to high molecular weight resins, thus the wood becomes more stable.

Dimension stability of impregnated wood was evaluated through TS and ASE tests. A Table 3 showed analysis of variance ( $\mathrm{F}$ test) for TS. The concentration and pressure time are shown to have affected signi-

Table 2. The PF-impregnated Falcataria wood's density properties at different PF concentrations and pressure times

\begin{tabular}{|c|c|c|c|c|c|c|c|}
\hline \multicolumn{4}{|c|}{ Phenol Formaldehyde $15 \%$} & \multicolumn{4}{|c|}{ Impregnation time 45 -minutes } \\
\hline $\begin{array}{l}\text { Time } \\
(\min )\end{array}$ & $\begin{array}{c}\text { Density-0 } \\
\left(\mathrm{g} / \mathrm{cm}^{3}\right)\end{array}$ & $\begin{array}{c}\text { Density-1 } \\
\left(\mathrm{g} / \mathrm{cm}^{3}\right)\end{array}$ & $\begin{array}{c}\text { Weight gain } \\
(\%)\end{array}$ & $\begin{array}{l}\mathrm{PF} \\
(\%) \\
\end{array}$ & $\begin{array}{c}\text { Density-0 } \\
\left(\mathrm{g} / \mathrm{cm}^{3}\right) \\
\end{array}$ & $\begin{array}{c}\text { Density-1 } \\
\left(\mathrm{g} / \mathrm{cm}^{3}\right) \\
\end{array}$ & $\begin{array}{c}\text { Weight gain } \\
(\%)\end{array}$ \\
\hline 0 & 0.26 & 0.26 & 0.00 & 0 & 0.26 & 0.26 & 0.00 \\
\hline 15 & 0.24 & 0.25 & 2.50 & 5 & 0.25 & 0.26 & 1.99 \\
\hline 30 & 0.25 & 0.25 & 3.25 & 10 & 0.27 & 0.27 & 2.63 \\
\hline 45 & 0.24 & 0.25 & 3.32 & 15 & 0.24 & 0.25 & 3.32 \\
\hline 60 & 0.28 & 0.29 & 6.23 & 20 & 0.27 & 0.29 & 7.87 \\
\hline 90 & 0.26 & 0.28 & 8.02 & 25 & 0.27 & 0.29 & 10.53 \\
\hline 120 & 0.28 & 0.30 & 7.12 & & & & \\
\hline
\end{tabular}

Note: Density-0: density before impregnation

Density-1: density after impregnation 

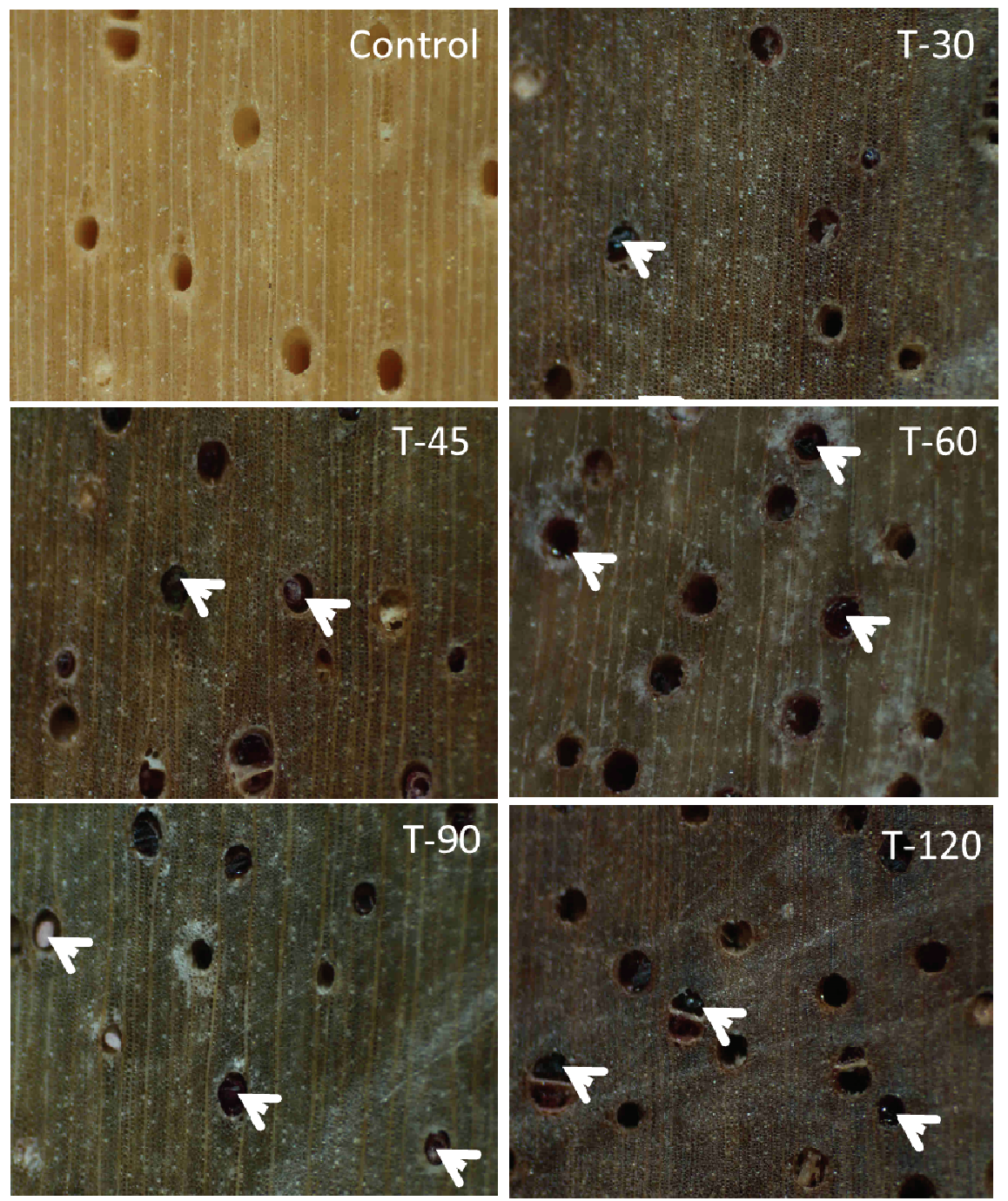

Fig. 1. Macrograph (50x magnification) of impregnated falcataria wood by $15 \%$ phenol formaldehyde (C; Control; T; Pressure Time, 30-120 Minutes). White arrows indicate the penetration of $\mathrm{PF}$ resin into the lumen.

ficantly at 99 and $95 \%$ confidence levels, respectively. According to Table 4 showed the TS results after the water immersion test. At 5\% PF concentration, the average thickness swelling was $6.10 \%$. However, as the PF concentration increases (10-25\%), the increase in thickness (TS) was significantly reduced compared to control and 5\% PF. The reduction of TS indicated the stability of impregnated wood. A $25 \%$ PF concentration could produce wood with good dimensional stability with an ASE value of $29 \%$. This result indicates that a high molecular weight PF could be used for Falcataria wood impregnation and significantly increased the wood's dimension stability at $99 \%$ confidence level (Table 3). 

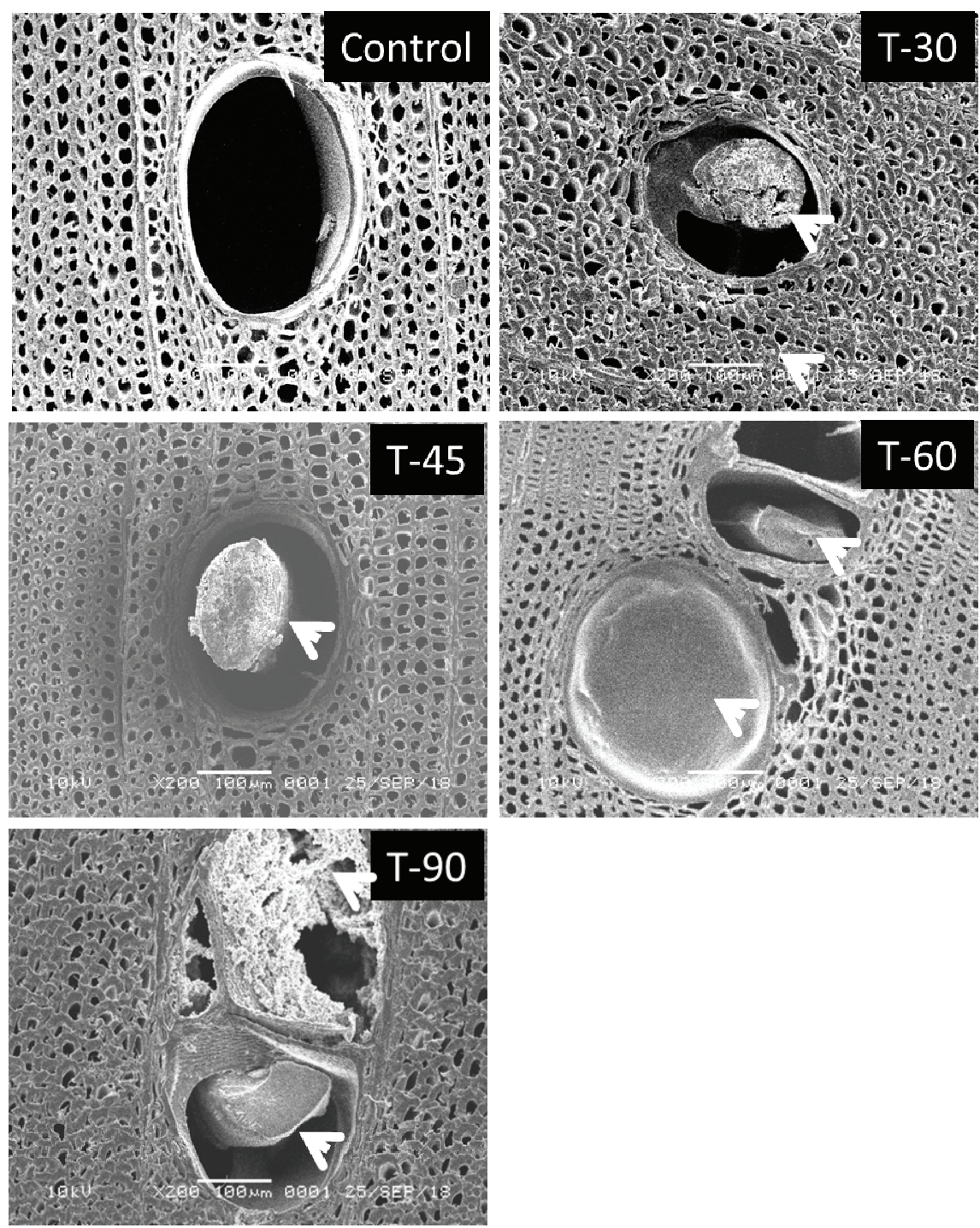

Fig. 2. Micrograph SEM of impregnated wood by 15\% PF (C; Control; T; Pressure Time, 45-90 Minutes). Scale bar of $100 \mu \mathrm{m}$. White arrows indicate the penetration of $\mathrm{PF}$ resin into the lumen.

Table 3. Analysis of variance results $(F$ test) for thickness swelling

\begin{tabular}{ccccc}
\hline Treatments & Sum of Square & df & F value & sig \\
\hline \hline Concentration & 9.594 & 5 & $6.959^{* *}$ & 0.001 \\
Pressure time & 2.832 & 6 & $2.851^{*}$ & 0.005 \\
\hline
\end{tabular}

** Highly significantly different $(\mathrm{P} \leq 0.001)$

* Significantly different $(\mathrm{P} \leq 0.005)$ 
Table 4. Thickness swelling of PF-impregnated Falcataria wood in volumetric at different conditions

\begin{tabular}{|c|c|c|c|}
\hline \multicolumn{2}{|c|}{ Treatment } & \multirow[b]{2}{*}{$\mathrm{TS}(\%)^{*, * *}$} & \multirow[b]{2}{*}{ ASE } \\
\hline \multirow{8}{*}{$\begin{array}{l}\text { Consentration } \\
\text { PF } 15 \%\end{array}$} & $\begin{array}{l}\text { Preasure time } \\
\quad(\min )\end{array}$ & & \\
\hline & Control & $6.11(0.40)^{\mathrm{a}}$ & \\
\hline & 15 & $.08(0.69)^{\mathrm{a}}$ & 0.43 \\
\hline & 30 & $5.98(0.69)^{\mathrm{a}}$ & 2.13 \\
\hline & 45 & $5.72(0.38)^{\mathrm{ab}}$ & 6.43 \\
\hline & 60 & $5.65(0.24)^{\mathrm{ab}}$ & 7.52 \\
\hline & 90 & $5.38(0.38)^{\mathrm{ab}}$ & 11.92 \\
\hline & 120 & $5.16(0.45)^{\mathrm{b}}$ & 15.55 \\
\hline \multirow{7}{*}{$\begin{array}{l}\text { Pressure time } \\
45 \text { minutes }\end{array}$} & $\begin{array}{c}\text { Concentration } \\
\text { PF }(\%)\end{array}$ & & \\
\hline & Control & $6.11(0.40)^{\mathrm{a}}$ & \\
\hline & 5 & $6.10(0.70)^{\mathrm{a}}$ & 0.09 \\
\hline & 10 & $5.77(0.25)^{\mathrm{a}}$ & 5.53 \\
\hline & 15 & $5.72(0.38)^{\mathrm{a}}$ & 6.43 \\
\hline & 20 & $5.28(0.78)^{\mathrm{a}}$ & 13.60 \\
\hline & 25 & $4.28(0.45)^{\mathrm{b}}$ & 29.92 \\
\hline
\end{tabular}

* Value in parentheses are standard deviations.

** Values followed by the same letter within the rows in each respond are not statistically different according to Duncan's multi range test.

The pressure time also affected TS and ASE in the same trend as the PF concentration. TS decreased with increasing pressure time, an indication that the wood stabilized more after a longer period of impregnation. In contrary to TS, ASE or stability dimension increased with increasing PF concentration. Fig. 1 showed macro images of impregnated wood at $15 \%$ PF concentration with different pressure times. A higher stability could be reached at a higher densification level (Table 2 and 4).

Wood specimens impregnated with PF for $120 \mathrm{mi}-$ nutes showed a darker color compared with the ones impregnated with shorter periods (i.e., 90, 60- and 30-minutes; see Fig. 1). This indicates that PF has successfully penetrated the compressed cells lumens, especially into the vessel cell. Indeed, wood samples with higher ASE values were obtained from a higher
PF concentration and longer pressure time (Table 4).

In this study, the highest stability value was achieved at 45 minutes of pressure time and $25 \% \mathrm{PF}$ concentration. This treatment was considered as an optimum impregnation condition which resulted in better physical properties and stability. A higher amount of PF entering the wood structure will trigger the wood's ability to expand again, a condition that could be maintained by curing PF resin. An explanation for this was offered by Shams et al. (2004) that mentioned the plasticizing effect of PF resins on wood cell walls. Therefore, the swelling ability can be reduced if the specimen was placed in a high moisture condition.

\subsection{Mechanical properties}

The young's modulus (MOE and MOR) of impregnated wood was increased after being treated by different concentrations and pressure timesat various treatments (Fig. 3 and 4). The impregnated wood showed a higher MOE compared to the control specimen. The increasing pressure time affected young's modulus up to 90 minutes and after that the value of young's modulus was stagnant. Young's modulus slightly increased gradually. This finding was also supported by density results (Table 2).

The effect of PF concentration on young's modulus has a similar trend with pressure time. The MOE increased from $4200 \mathrm{kgf} / \mathrm{cm}^{2}$ to $5800 \mathrm{kgf} / \mathrm{cm}^{2}$ (Fig. 4) or increased $47 \%$ compared to the control specimen. The MOE strength was created by polymerization of $\mathrm{PF}$ resin bonding process after the curing process was successful. This property could influence the resin allocation into the cell wall (Fig. 2). Besides that, excess resin during the impregnation process may change the cell structure which was darker than the control specimen when the resin was forced to fill up the porous components. A possible explanation is a fact that a high amount of concentrated resin did not makethe 

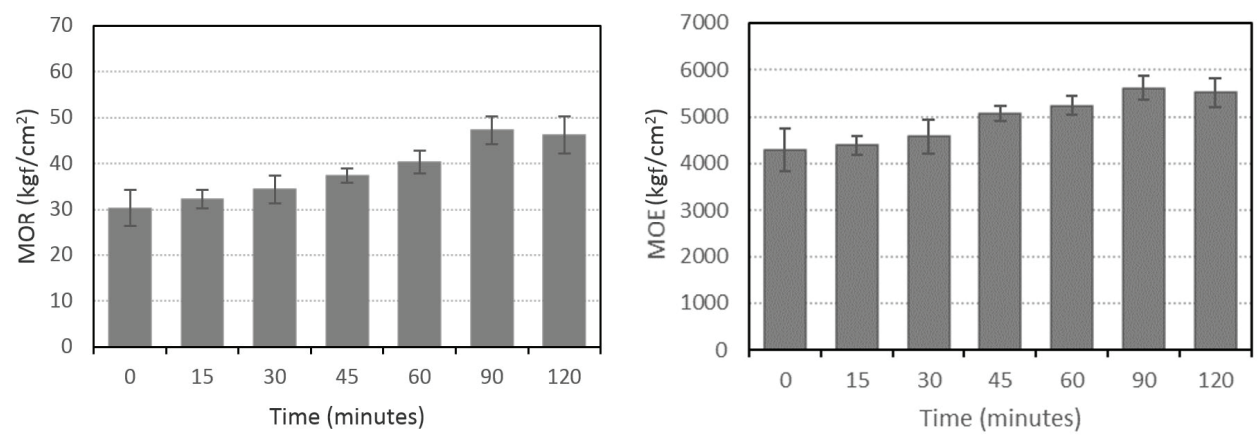

Fig. 3. The young's modulus of PF-impregnated Falcataria wood of $15 \%$ PF at different pressure times.
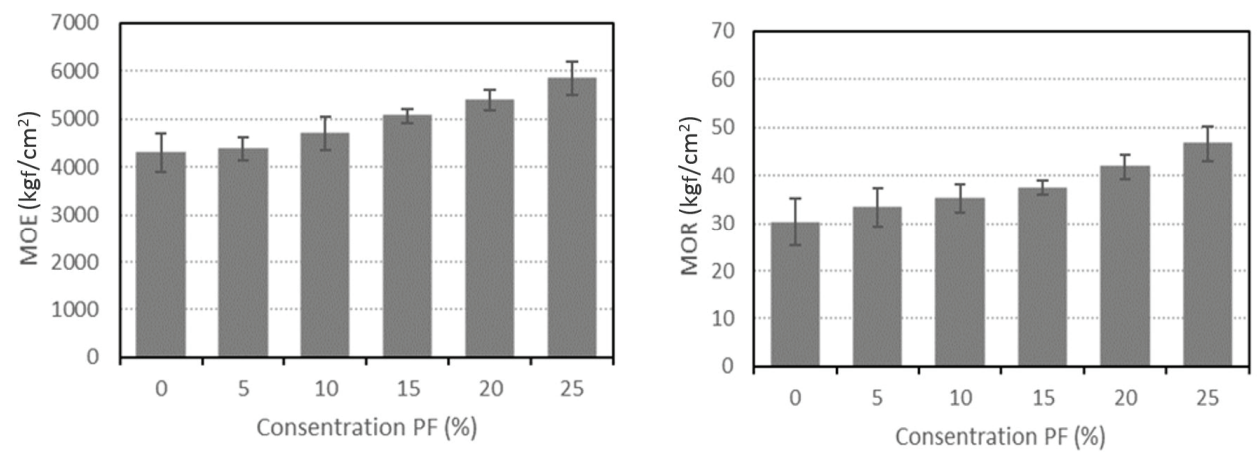

Fig. 4. The young's modulus of PF-impregnated Falcataria of 45 minutes pressure time at different PF concentration.

samples brittle because WPG was only increased by $10 \%$ (Table 2). In general, high dimensional stability could be achieved by a high WPG by combining high PF concentration and longer pressure time. High WPG increased the wood's mechanical properties due to the presence of $\mathrm{PF}$ in wood tissue which made it more rigid.

\section{CONCLUSION}

Dimensional stability and mechanical properties of Falcatariawood were successfully improved through the impregnation process using phenol formaldehyde resin. The impregnation process of PF was able to improve the mechanical properties and the density from
$0.26 \mathrm{~g} / \mathrm{cm}^{3}$ to $0.30 \mathrm{~g} / \mathrm{cm}^{3}$ with only $10 \%$ weight percent grain. The dimensional properties improved along with increasing resin concentration and pressure time. A higher increase in Young's modulus was reached at the higher resin concentration levels. The darkened color of impregnated-wood was associated with more PF penetrated into the wood's cells.

\section{ACKNOWLEDGMENT}

The authors thank Institut Teknologi Bandung for funding this research through the Research and Community Service and Innovation Program 2017. The comments from anonymous reviewers are greatly acknowledged. 


\section{REFERENCES}

Arsyad, W.A.M., Basri, E., Hendra, D., Trisatya, D.R. 2019. Termite resistance of impregnated Jabon wood (Anthocephalus Cadamba Miq.) with combined impregnant agents. Journal of the Korean Wood Science and Technology 47(4): 451-458.

Biziks, V., Bicke, S., Militz, H. 2019. Penetration depth of phenol-formaldehyde (PF) resin into beech wood studied by light microscopy. Wood Scienceand Technology 53(1): 165-176.

[BS] British Standard 1957. Methods of testing small clear specimens of timber

Chang, Y.S., Han, Y., Eom, C.D., Chun, S., Yeo, H. 2019. Hygroscopic property of heat-treated Yellow Poplar (Liriodendron tulipifera) Wood. Journal of the Korean Wood Science and Technology 47(6): 761-769.

Farmer, R.H. 1967. Chemistry in the utilization of wood. Pergamon Press, New York.

Franke, T., Mund, A., Lenz, C., Herold, N., Pfriem, A. 2017. Microscopic and macroscopic swelling and dimensional stability of beech wood impregnated with phenol-formaldehyde. Pro Ligno 13(4): 373-378.

Franke, T., Herold, N., Buchelt, B., Pfriem, A. 2018. The potential of phenol-formaldehyde as plasticizing agent for molding applications of wood veneer: Two-dimensional and three-dimensional molding. European Journal of Wood and Wood Products 76(5): 1409-1416.

Furuno, T., Imamura, Y., Kajita, H. 2004. The modification of wood by treatment with low molecular weight phenol-formaldehyde resin: A properties enhancement with neutralized phenolic-resin and resin penetration into wood cell walls. Wood Science and Technology 37(5): 349-361.

Gabrielli, C., Kamke, F.A. 2010. Phenol-formaldehyde impregnation of densified wood for improved di- mensional stability. Wood Science and Technology 44(1): 95-104.

Grinins, J., Biziks, V., Irbe, I., Rizhikovs, J. 2019. Water related properties of Birch wood modified with Phenol-Formaldehyde (PF) Resins. Key Engineering Materials 800: 246-250.

Hadi, Y.S., Massijaya, M.Y., Zaini, L.K., Pari, P. 2019. Physical and mechanical properties of methyl methacrylate-impregnated wood from three fastgrowing tropical tree species. Journal of the Korean Wood Science and Technology 47(3): 324-335.

Hartono, R., Hidayat, W., Wahyudi, I., Febrianto, F., Dwianto, W., Jang. J.H., Kim, N.H. 2016. Effect of phenol formaldehyde impregnation on the physical and mechanical properties of soft-inner part of oil Palm Trunk. Journal of the Korean Wood Science and Technology 44(6): 842-851.

Hill, C. 2006.Wood modification: chemical, thermal and other Processes. Wiley, England

Izreen, F.A.N., Zaidon, A., Adawiah, M.A.R., Bakar, E.S., Paridah, M.T., Hamami, S.M., Anwar, U.M.K. 2011. Enhancing the properties of low-density hardwood dyera costulata through impregnation with phenolic resin admixed with formaldehyde scavenger. Journal of Applied Sciences 11(20): 3474-3481.

Lee, J.M., Lee, W.H. 2018. Dimensional stabilization through heat treatment of thermally compressed wood of Korean Pine. Journal of the Korean Wood Science and Technology 46(5): 471-485.

Kamke, F.A. 2006. Densified radiata pine for structural composites. Maderas. Ciencia Y Tecnología 8(2): 83-92.

Oh, S.W., Park, H.J. 2015. Vacuum pressure treatment of water-soluble melamine resin impregnation for improvement of mechanical property, abrasion resistance and incombustibility on softwood. Journal of the Korean Wood Science and Technology 43(6): 792-797. 
Priadi, T., Sholihah, M., Karlinasari, L. 2019. Water absorption and dimensional stability of heat-treated fast-growing hardwoods. Journal of the Korean Wood Science and Technology 47(5): 567-578.

Rowell, R.M. 1999. Wood handbook: Specialty treatments, Chap. 19. USDA general technical report FPL-GTR-113 USDA, Madison

SAS Institute Inc. (2004). SAS/STAT Software, Version 9.1. Cary. URL http://support. sas.com/document ation/onlinedoc/91pdf/index_91.html

Shams, M.I., Yano, H., Endou, K. 2004. Compressive deformation of wood impregnated with low molecular weight phenol formaldehyde (PF) resin I:
Effects of pressing pressure and pressure holding. Journal of Wood Science 50: 337-342.

Shams, M.J., Yano, H. 2004. Compressive deformation of wood impregnated with low molecular weight phenol formaldehyde (PF) resin II: effects of processing parameters. Journal of Wood Science 50: 343-350.

Stamm, A.J. 1959. The dimensional stability of wood. Forest Product Journal 9(10): 375-381.

Stamm, A.J., Baechler, R.H. 1960. Decay resistance and stability of five modified Woods. ForestProduct Journal 10(1): 22-26. 